\title{
Chlorophyll-a MODIS mesoscale variability in the Inner Sea of Chiloé, Patagonia, Chile (41-43ํㄱ): Patches and Gradients?
}

\author{
Variabilidad a mesoescala de la Clorofila- $a$ MODIS en el Mar Interior de

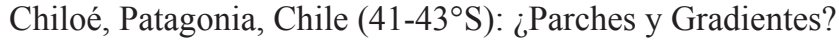

\author{
Carlos Lara ${ }^{1}$, Marcelo Miranda ${ }^{1}$, Vivian Montecino² and José Luis Iriarte ${ }^{3}$
}

\author{
${ }^{1}$ Departamento de Ecosistemas y Medioambiente, Pontificia Universidad Católica de Chile, Av. Vicuña Mackenna 4860, Santiago, \\ Chile.mmirands@uc.cl \\ ${ }^{2}$ Departamento de Ciencias Ecológicas, Universidad de Chile, Casilla 653, Las Palmeras 3425, Santiago, Chile \\ ${ }^{3}$ Instituto de Acuicultura, Centro de Investigación en Ecosistemas de la Patagonia-CIEP, Centro de Investigación en Nutrición-CIEN, \\ Centro Basal COPAS-Sur Austral, Universidad Austral de Chile, Los Pinos S/N, Puerto Montt, Chile
}

\begin{abstract}
Resumen.- Las imágenes satelitales son una poderosa herramienta para describir estructuras espaciales a meso y macroescala, ayudando de esta manera en la comprensión de los procesos físicos-biológicos que ocurren en el océano. El objetivo de este estudio fue establecer la variabilidad espacial (horizontal) y temporal (estacional) de la biomasa autotrófica medida como concentración de clorofila satelital (Clo-a) en el Mar Interior de Chiloé (41,0$43,5^{\circ} \mathrm{S}$ ). Aproximaciones de percepción remota (MODIS) y geoestadísticas (Variogramas) fueron usadas para caracterizar la estructura espacial de la Clo- $a$ en la capa superficial por estimación afototrópica de valores promedios de Clo- $a$. Un total de 27 imágenes fueron analizadas y agrupadas en estaciones de verano, primavera, invierno y otoño para el Mar Interior de Chiloé durante el periodo de enero 2003-diciembre 2005. El análisis de imágenes apunta a un patrón clásico para la dinámica de la biomasa autotrófica de áreas costeras temperadas, con altos valores de Clo- $a$ en las estaciones de primavera-verano y ocurrencia de bajos valores durante las estaciones de otoño-invierno. El análisis espacial indica que la Clo- $a$ se distribuye en parches mayores a $50 \mathrm{~km}$ los cuales son más homogéneos durante las estaciones de otoñoinvierno, mientras que parches más pequeños que $30 \mathrm{~km}$ y más heterogéneos fueron observados durante primaveraverano. El análisis de anisotropía muestra un ángulo predominante de orientación en la dirección este-oeste, sugiriendo el rol de la estratificación de la columna de agua como un proceso modulador de la variabilidad espacial superficial de la Clo- $a$ en el Mar Interior de Chiloé.
\end{abstract}

Palabras clave: Anisotropía espacial, variogramas, clorofila fitoplancton, fiordos patagónicos

\begin{abstract}
Satellite images are powerful tools to describe meso- and large-scale spatial structures, thus helping in the comprehension of the physical-biological processes taking place in the ocean. The objective of this study was to establish spatial (horizontal) and temporal (seasonal) variability of the autotrophic biomass measured as satellite chlorophyll concentrations (Chl- $a$ ) in the Inner Sea of Chiloé (41.0-43.5'S). Remote sensing (MODIS) and geostatistics (Variograms) approaches were used to characterize Chl- $a$ spatial-horizontal structure at the surface layer by anisotropic estimation of the Chl- $a$ average values. A total of 27 selected images were analyzed and grouped into summer, spring, fall and winter seasons during the January 2003-December 2005 period. Image temporal analysis showed a classic pattern for the autotrophic biomass dynamics of cold temperate coastal areas, with highest Chl- $a$ values occurring during the spring-summer period, and the lowest values during the fall-winter season. Image spatial analysis indicated that $\mathrm{Chl}-a$ is distributed into more homogeneous and larger than $50 \mathrm{~km}$ patches, during the fall-winter seasons, whereas during the spring-summer seasons more heterogeneous and smaller than $30 \mathrm{~km}$ patches were found. The anisotropy analysis showed a predominant angle in the East-West direction, suggesting the role of water column stratification as a modulating process of surface Chl-a spatial variability in the Inner Sea of Chiloé area.
\end{abstract}

Key words: Spatial anisotropy, variograms, phytoplankton chlorophyll, Patagonian fjords

\section{INTRODUCTION}

One of the main properties of phytoplankton assemblages in the coastal ocean is their spatial and temporal heterogeneity, as a result of oceanic climate variability, acting at multiple ecological scales. The structure and spatial-temporal dynamic of phytoplankton is an important feature that determines the timing and flow of energy and matter through coastal marine ecosystems food webs (Therriault \& Platt 1978, Marín et al. 2003). In marine and 
terrestrial systems, spatial patterns indicate that both errant and sessile organisms are rarely randomly distributed, so it is usual to find aggregates, patches or gradients for both types of life forms (Geider et al. 1998, Legendre \& Legendre 2003, Miranda 2007). In ecological studies, one of the first steps in understanding processes is to identify spatial and temporal patterns. Further, these ecological data are usually characterized by spatial structures due to spatial autocorrelation. Thus, the magnitude, intensity, as well as extent of spatial autocorrelation can be quantified using spatial statistics (Fortin 1999, Fortin et al. 2002).

The spatial distribution patterns in many ecological datasets have revealed both scale dependence and direction dependence (directionality, or anisotropy), with the former referring to changing characteristics at multiple scales, and the latter, different patterns in different directions (Wang \& Yu 2005, Wang et al. 2007). In terms of isotropy and anisotropy, spatial dependence is a fundamental feature in the modeling of natural resources in space (Austerlitz et al. 2007). Nevertheless, the anisotropy of spatial patterns has received little attention (Rosenberg 2004). The existence of anisotropy associated to primary and secondary production has been determined by the spatial distribution of Acacia caven (Gerstmann et al. 2010) and Pinus radiata (Miranda 2007). This anisotropy, would be the result of self-organization processes at the ecosystem level (energy dissipation), occurring as an answer to (direct and indirect) environmental influence factors and which are observable at different spatial and temporal scales.

Satellite images, processed by variograms have been of great usefulness for the study of spatial heterogeneity of vegetation in terrestrial (Garrigues et al. 2006, Miranda 2007) and aquatic ecosystems (Michelakaki \& Kitsiou 2005). At a global scale and through image analysis from CZCS (Coastal Zone Color Scanner) and SeaWIFs (The Sea-viewing Wide Field-of-view Sensor), it has been shown that the chlorophyll- $a(\mathrm{Chl}-a)$ biomass is positively related to latitude in the Pacific Ocean (Gregg \& Conkright 2002). At the regional scale, Chl- $a$ filaments have been detected in the northern zone of the Humboldt Current System (Marín et al. 2003), that result in permanent or seasonal structures with strong ocean-coast Chl- $a$ gradients (Yuras et al. 2005, Montecino et al. 2006).

In the Patagonian region $\left(40-55^{\circ} \mathrm{S}\right)$ of western South America (Poleward Undercurrent and Cape Horn Current, Strub et al. 1998), the oceanographic characterization by satellite images of variables such as temperature and Chl- $a$ is scarce. Specifically, studies in situ have shown a clear seasonal variability of Chl- $a$ in the Inner Sea of Chiloé
(40-43을 ${ }^{\circ}$, with a main spring bloom (Palma \& Silva 2004, Ramírez \& Pizarro 2005, Iriarte et al. 2007, Montecino et al. 2009). Furthermore, the existence of an East-West spatial gradient at a scale of kilometers, in the taxa composition of phytoplankton blooms has been proved and related to oceanographic distinctive features (Iriarte et al. 2007). These studies have focused on explaining variability of the autotrophic biomass in time, in specific areas with special emphasis on the temporal monitoring (monthly, seasonal, annual). Additionally, a complexity exists in the Inner Sea of Chiloé, given mainly by (1) the presence of micro-basins and geographical barriers (Palma \& Silva 2004), (2) that this marine environment is affected by high precipitation (2000-5000 $\mathrm{mm} \mathrm{year}^{-1}$ ) and high river flow down the east coast $\left(100-600 \mathrm{~m}^{3} \mathrm{~s}^{-1}\right)$, (3) that it is a semiclosed environment, exposed to the oceanic regime in west oceanic side, and (4) that it is a region intensively used for anthropogenic productive activities such as aquaculture. Therefore, the knowledge of the spatial structure patterns of phytoplankton assemblages constitutes an important feature to understand the phytoplankton bloom dynamics (e.g., initiation, development, termination) on Patagonian coastal marine system. It is thus expected that a close association between seasonal variability of Chl- $a$ (e.g., spring versus winter) and its spatial structure (patchiness versus gradient) in the north-occidental Patagonian region would appear.

In this context we hypothesized that the spatial structure of the phytoplankton, given by spatial heterogeneity (degree of clustering in patches and gradients), in the Inner Sea of Chiloé is strongly related with its own seasonal variability. Thus the aim of this study was to evaluate the spatial structure of the satellite Chl- $a$ in the Inner Sea of Chiloé at mesoscale (10-100 km) during contrasting seasons for 2003-2005. We performed geostatistical and anisotropic analyses on Chl- $a$ estimates from satellite Images from the MODIS-AQUA sensor to elucidate the main surface spatial features of the phytoplankton biomass (using Chl- $a$ as a proxy) of this marine area.

\section{Material AND MethodS}

\section{STUdY AREA}

The Inner Sea of Chiloé in the South-East Pacific Ocean, covers from the Reloncaví Inlet in the north to the Corcovado Gulf Mouth in the south $\left(41.5-43^{\circ} \mathrm{S}\right)$ (Fig. 1). This region is characterized by depths from 50 to $400 \mathrm{~m}$, and receives freshwater contribution from high precipitation/snow from 2000 to $5000 \mathrm{~mm} \mathrm{year}^{-1}$, and river discharges following 
in a nival regime (Reloncaví and Comau Fjords), hence the freshwater contribution increases during the months of winter and spring. In order to determine the spatial and temporal Chl- $a$ structure, satellite MODIS (Moderated Resolution Imaging Spectroradiometer) images belonging to the AQUA platform were used daily and obtained from the NASA website ${ }^{1}$. A total of 27 images were selected for three years, with an L2 level of processing between January 2003 and December 2005. The images were georeferenced to the coastline (DATUM WGS 84, Zone $18 \mathrm{~S}$ ), and exported to ArcGis 9.3 in ASCCI format. To obtain the data from the images, a random sampling of the study area was made, forming a sample of 1000 points. The satellite Chl- $a$ values were extracted for each daily image, obtaining in this way 1000 columns x 27 rows. The

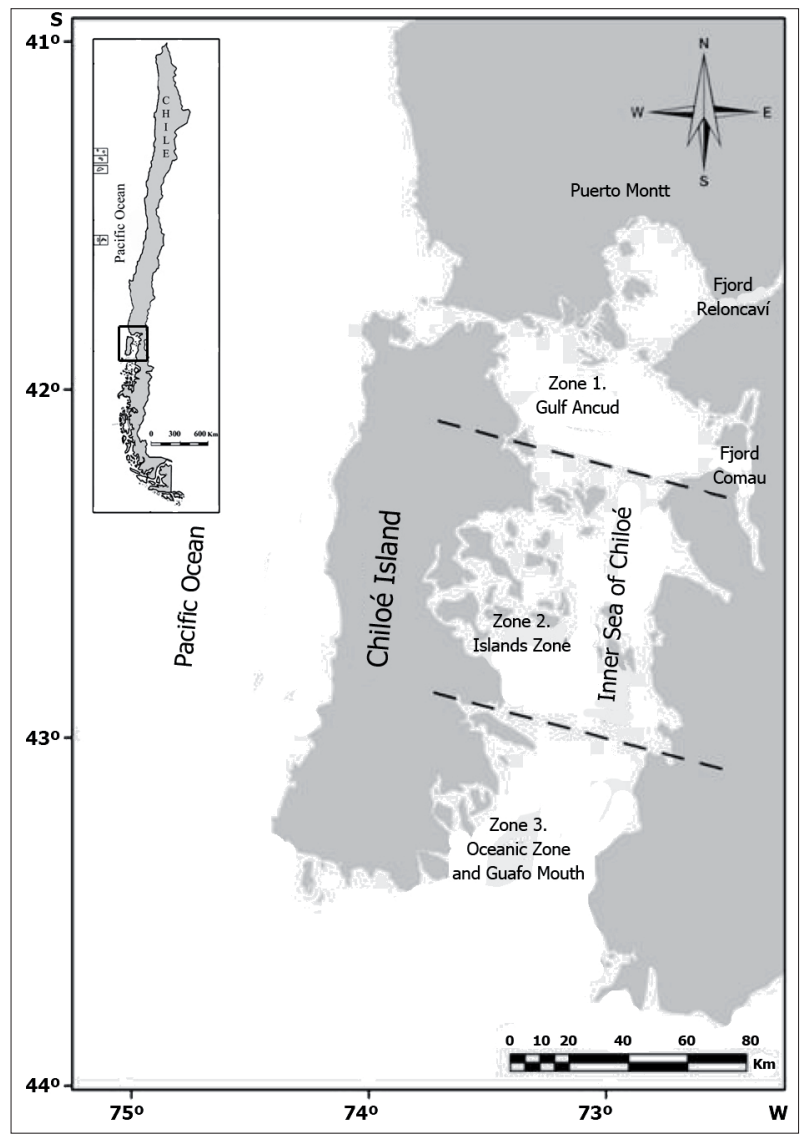

Figure 1. Study area showing the three zones analyzed in the Inner Sea of Chiloé (41.5-43을 during 2003-2005 period / Área de estudio donde se muestran las tres zonas analizadas en el Mar Interior de Chiloé $\left(41,5-43^{\circ} \mathrm{S}\right)$ durante el periodo 2003-2005 geographic coordinates in $\mathrm{X}$ and $\mathrm{Y}$ were specified for each sample point (pixel).

The study excluded from analysis all data from MODIS images situated less than $1,000 \mathrm{~m}$ from the coasts, so as to avoid the anthropogenic effect and the dovetailing due to other substances (detritus, dissolved organic matter, colored substances) which could compete optically with the Chl- $a$ observed by the sensor.

The analyses were performed with the ENVI 4.2 image processing system ${ }^{2}$ and ArcView GIS 9.3 geographical information system ${ }^{3}$.

\section{Data Analysis}

\section{TeMPORAL ANALYSIS}

The procedure for the analysis of the time series Chl- $a$ values, consisted in dividing the study area in three zones (Fig. 1): a) Zone 1 corresponds to the Gulf of Ancud, and the area adjacent to the Reloncaví Fjord, b) Zone 2, corresponds to the islands area, located at the centre of Inner Sea of Chiloé and c) Zone 3, which corresponds to the oceanic area and the Guafo mouth area. The purpose of characterizing different zones in the space-temporal distribution of the phytoplankton was to represent the different sub-basins of the Inner Sea of Chiloé: The Reloncaví area versus el Guafo (González et al. 2010) and an intermediate transition area of the inner islands using topographic and hydrographic criteria (Tello \& RodríguezBenito 2009, Montecino et al. 2009).

A mean test between zones based on the confidence intervals obtained by the bootstrap re-sampling, was applied to verify if significant differences existed in the temporal behavior of the Chl- $a$ in the study area (Chernick 1999).

\section{Spatial ANALYsis}

For the structural data analysis, (spatial variability and anisotropy), experimental variogram functions were used, as well as cartogram according to:

$$
\gamma(h)=\frac{1}{2 N} \sum_{i=1}^{\mathrm{n}}\left\{Z\left(\chi_{t}\right)-Z\left(\chi_{t}+h\right)\right\}^{2}
$$

1http://modis.gsfc.nasa.gov/

${ }^{2}$ Research Systems, Inc., Colorado, USA, 2005

3Environmental Systems Research Institute Inc., California, USA, 1991 
Where: $\gamma(h)$ is the semi variance of the $Z$ variable at the distance of $h ; z\left(x_{\mathrm{i}}\right)$ is the value of the variable examined in the position $\left(x_{\mathrm{i}}\right) ; z\left(x_{\mathrm{i}}+h\right)$ is the value of the variable examined in the position $\left(x_{\mathrm{i}}+h\right)$, while $N$ corresponds to the number of pair samples separated by a distance $h$ (Burrough 1996).

This function is one of the most important in the determination of the variability and spatial correlation characteristics of the phenomenon under study, as it tries to explain the ecological processes, taking the spatial distribution of its features into account (Turner et al. 2001, Fortin \& Dale 2005). In this analysis, the defined range was determined as the distance at which the spatial structure varies, that is, the maximum distance at which the studied variable is spatially self-correlated. Over this range, the distance between two semi-variance pairs of $\mathrm{z}\left(\mathrm{x}_{\mathrm{i}}\right)$ and $z\left(x_{i}+h\right)$, does not affect the spatial structure of the variable and the semi variance values become constant and are named at this point maximum variability (MirandaSalas \& Condal 2003, Fortin \& Dale 2005). Both functions measure the dissimilarity or variability between two values, separated by a certain distance and expressed by the semi-variance (Isaaks \& Srivastava 1989). Although the extent of spatial structure depends heavily on the method of analysis used (Waters et al. 2003), variogram maps used in this study for the determination of anisotropy resulted into a key tool for the identification of the form of the spatial structure (Legendre \& Fortin 1989, Legendre \& Legendre 2003). This analysis includes all the information concerning spatial variation of the response variable (Michelakaki \& Kitsiou 2005).

The spatial dependence between values of the variable analyzed in the present study, was estimated with variograms with a $3.5 \mathrm{~km}$ "lag" for each image and a maximum distance of analysis of $50 \mathrm{~km}$. Anisotropy directions were visually determined once the experimental variograms were plotted into variogram maps. All spatial analyses were performed using the S-Plus $6.0^{4}$ and GS+ $7.0^{5}$ statistical analysis programs.

\section{Results}

\section{Temporal analysis}

The images of Chl- $a$ from January 2003 to December 2005 presented a marked seasonal periodic variability (Fig. 2),

${ }^{4}$ Insightful Corp., Washington, USA, 1990

${ }^{5}$ Gamma Design Software, Michigan, USA, 1996

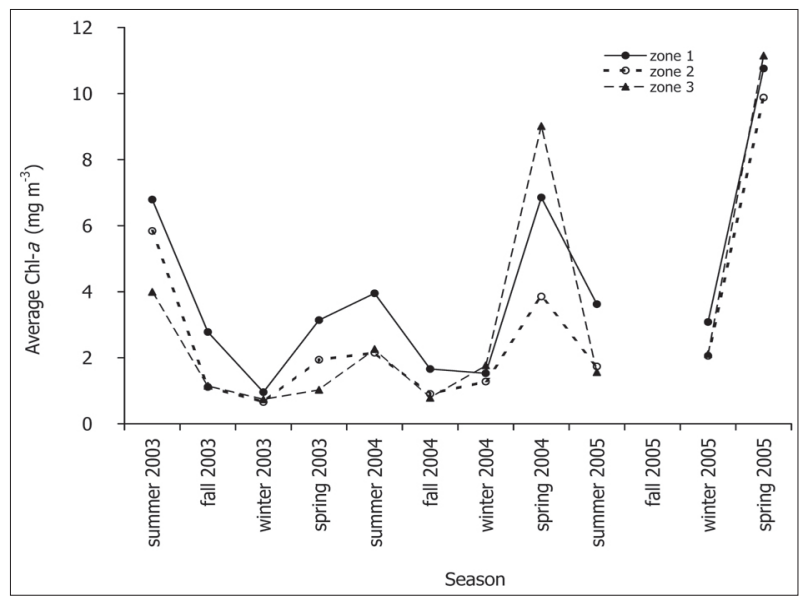

Figure 2. Temporal variation of average concentration of $\mathrm{Chl}-a$ in zones 1, 2 and 3 in the Inner Sea of Chiloé between the years 20032005 / Variación temporal de concentración promedio de Clo- $a$ en las zonas 1,2 y 3 en el Mar Interior de Chiloé entre los años 2003-2005

where higher Chl- $a$ values were registered in SpringSummer, while lower values were observed in AutumnWinter.

Chl- $a$ spatial distribution by area: Zone 1, (Ancud Gulf), showed the higher average value (4.10 mg Chl- $a$ $\mathrm{m}^{-3}$ ), followed by Zone 3 (Oceanic Zone and Guafo mouth) with an average of $3.23 \mathrm{mg} \mathrm{Chl}-a \mathrm{~m}^{-3}$ and an average value lower than $2.86 \mathrm{mg} \mathrm{Chl}-a \mathrm{~m}^{-3}$ was observed in Zone 2 (Island Zone). The statistical analysis based on confidence intervals obtained by "bootstrap" showed significant differences between Zones 1 and 2, and Zones 1 and 3. There were no significant differences in the Chl-a concentration between Zones 2 and 3 (Table 1).

\section{Spatial Analysis}

During the spring and summer seasons, a higher spatial heterogeneity is observed, represented by higher values of maximum variability $(13.84+/-7.07 ; 13.63+/-10.31$ $\mathrm{mg}$ Chl- $a \mathrm{~m}^{-3}$, respectively), as compared to autumn and winter $\left(1.27+/-0.09 ; 1.98+/-3.05 \mathrm{mg} \mathrm{Chl}-a \mathrm{~m}^{-3}\right)$ which are spatially more homogeneous. This spatial behavior is strongly related to the temporal behavior of Chl- $a$ through time (Fig. 3a).

In relation to the spatial variability extension, it was observed that the range presented a trend to increase in the autumn (49367 +/- 9000) and winter (48589 +/- 12000), and to decrease in spring $(31233+/-8875)$ and summer (30006 +/- 8829), contrary to the behavior observed for Chl- $a$ (Fig. 3b). Based on levels of heterogeneity and extension expressed in maximum variability and range, it 


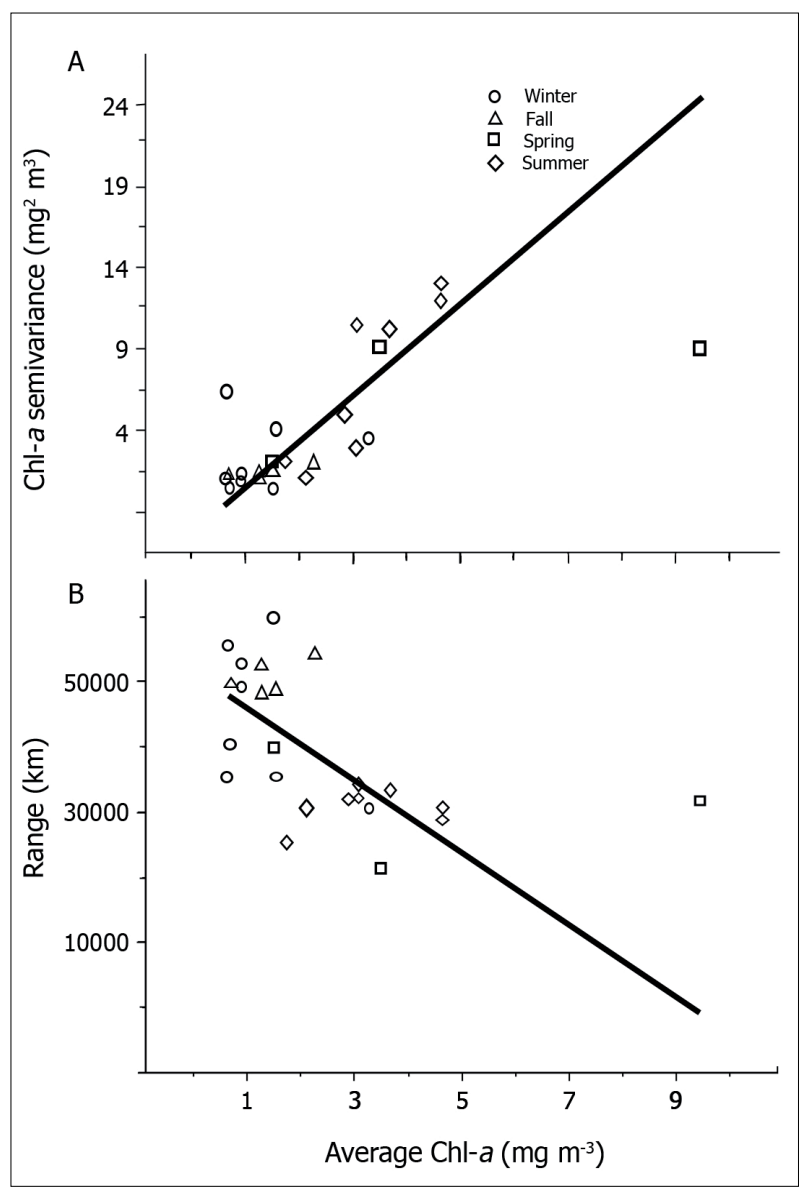

Figure 3. A) Seasonal semivariance of Chl- $a$ versus average $\mathrm{Chl}-\mathrm{a}$ in the Inner Sea of Chiloe between the years 2003-2005 and B) Seasonal range of variability of Chl- $a$ versus average $\mathrm{Chl}-a$ in the Inner Sea of Chiloé from 2003 to 2005 /A) Semivarianza estacional de Clo- $a$ versus Clo- $a$ en el Mar Interior de Chiloé durante los años 2003-2005 y B) Rango de variabilidad de Clo-a versus Clo- $a$ en el Mar Interior de Chiloé desde 2003 a 2005

is possible to indicate that Chl- $a$ forms spatial structures of phytoplankton biomass patches. These patches would tend to be more heterogeneous and spatially smaller in spring-summer (maximum variability $=13.73$; range $=30$ $\mathrm{km})$ and more homogeneous and spatially more extensive in autumn-winter (maximum variability $=1.63$, range $=50$ $\mathrm{km})$.

\section{AnISOTropy}

From the 27 satellite selected images, analyzed using variogram maps, 18 (67\%) presented evident anisotropy and $9(33 \%)$ showed clear isotropy, which tends to change during the different seasons. Anisotropy angles varied between $45^{\circ}$ and $135^{\circ}$, depending on the season: in autumn the main direction was $135^{\circ}(11 \%)$, in winter, $90^{\circ}(19 \%)$ and in summer from $0^{\circ}$ to $45^{\circ}(26 \%)$. On the other hand, spring always showed a clear isotropic behavior. Through the selection of the most representative variogram maps of each season, it was observed that the main axis represents lower spatial variability in Chl- $a$ concentration for the study area (Fig. 4).

\section{Discussion}

Chl- $a$ ranges in the Inner Sea of Chiloé correspond to those values found for highly productive zones, such as coastal upwelling areas, from the Humboldt Current System (Bahía de Valparaíso, $32^{\circ} \mathrm{S}: 3.8-13.2 \mathrm{mg}$ Chl $-a \mathrm{~m}^{-3}$, Avaria 1975, Avaria \& Orellana 1975; Bahía de Mejillones, $23^{\circ} \mathrm{S}$ : 0.5-50.0 mg Chl- $a \mathrm{~m}^{-3}$, Rodríguez et al. 1986, Iriarte \& González 2004; Bahía de Concepción, 36 S: 1.0-35.0 mg Chl- $a$ m $^{-3}$, González et al. 1989, Ahumada et al. 1991; Iquique, $18-24^{\circ} \mathrm{S}$ : $0.5-2.0 \mathrm{mg} \mathrm{Chl}-a \mathrm{~m}^{-3}$, Morales et al. 1996). These values are included in the range observed in previous studies of the study area $(0.05$ and $30.0 \mathrm{mg}$ Chl- $\left.a \mathrm{~m}^{-3}\right)$, through satellite images SeaWifs with a marked seasonality of high concentrations of autotrophic biomass during spring-summer (September-March), and low concentrations during winter (May-August) (Iriarte et al. 2007, Tello \& Rodríguez-Benito 2009).

An increase of the photosynthetic activity (and therefore an increase of the biomass) during spring is associated to an increase in the spatial disorder ot ther phytoplanktonic biomass, therefore determining a more heterogeneous system in the Inner Sea of Chiloé (Fig. 3a). This biomass increase could be associated to oceanic fronts observed in the Patagonian region (Acha et al. 2004), characterized by strong salinity gradients from West-East, given the strong influence of freshwater in the interior zone of the fjords and channels. The high frequency of South West winds during spring and summer, results in the advection of dissolved inorganic nutrients (nitrate and orthophosphate) from the oceanic zone, towards the euphotic layer of the inner waters, generating high phytoplankton biomass and PP estimates (up to $4 \mathrm{gC} \mathrm{m}^{-2} \mathrm{~d}^{-1}$; Iriarte et al. 2007). Furthermore, the magnitude of the primary production may be result of the interplay of high availability of light and the presence of euphotic layer nutrients during early spring (Iriarte et al. 2007, Tello \& Rodríguez-Benito 2009). On the contrary, the lower phytoplankton biomass during autumn-winter suggests the strong effect of the reduction in light availability (Strub et al. 1998, Montecino et al. 2009) and hence the spatial homogeneity of the phytoplankton biomass in the study area. These spatial patterns of the autotrophic biomass coincide with the 
Table 1. Result of mean test between zones based on Bootstrap confidence accelerated intervals (BCa) / Resultado de la prueba de medias entre zonas basado en intervalos de confianza (BCa) obtenidos por Bootstrap

\begin{tabular}{ccccc}
\hline & \multicolumn{5}{c}{ Percentiles BCa } \\
Median differences & $2.5 \%$ & $5 \%$ & $95 \%$ & $97.5 \%$ \\
\hline Zone 1 - Zone 2 & 0.7 & 0.9 & 1.8 & 1.9 \\
Zone 1 - Zone 3 & 0.2 & 0.3 & 1.6 & 1.7 \\
Zone 2 - Zone 3 & -1.4 & -1.3 & 0.12 & 0.19 \\
\hline
\end{tabular}

patterns observed in land ecology, where there is a strong relationship between the activity of productivity and its spatial heterogeneity in time. In this respect, in the Acacia caven matorral, an increase in the photosynthetic activity of the community in spring coincides with an increase in spatial heterogeneity, mainly as a product of the increase in temperature and accumulation of water in the soil (Gerstmann et al. 2010). A similar situation is observed in fall-winter where an adverse condition in terms of temperature and precipitation generates a decrease of the potential productivity and a spatially more homogeneous system. In our study and due to the relationship existing between the intensity of phytoplankton productivity and its spatial structure, it is possible to observe a smaller range in the homogeneity of the autotrophic communities during spring-summer (Fig. 3b) that means, as the amount increases due to environmental conditions, the system becomes more patchy in its spatial distribution.

Wind stress play an important role for lateral hydrodynamics in estuarine systems and fjords: winds coming from the south and southeast (Cáceres et al. 2002), coupled with seasonal changes in limitation of light and inorganic nutrients (Iriarte et al. 2007), could be playing an important role in the formation of smaller sized patches, as well as greater phytoplankton biomass, during spring and summer. The outcome of the spatial analysis indicate the existence of a clear spatial structure in the form of patches of phytoplankton communities in the Inner Sea of Chiloé, during the whole analyzed period according to seasons. The highest range values obtained correspond to a $50 \mathrm{~km}$ scale, observed during autumn and winter. This suggests that there is a lower phytoplankton biological activity, and a lesser spatial variability of Chl- $a$ in the marine region. On the contrary, in spring-summer, smaller ranges and greater variability were estimated, resulting in smaller sized patches $(30 \mathrm{~km})$ and with higher phytoplankton biomass (> $\left.4 \mathrm{mg} \mathrm{Chl}-a \mathrm{~m}^{-3}\right)$. In this respect, the formation of patches in the distribution of planktonic communities can be the result of biological interactions between species of the same group (i.e., competition for nutrients) and predatorprey (i.e., grazing), as well as physical factors (i.e., wind and water mass) to determine a mosaic with structures varying between 1 to $100 \mathrm{~km}$ (Tzella \& Haynes 2006). Submesoscale planktonic patterns $(0.1-100 \mathrm{~km})$ occur in estuaries and coastal marine systems where physical and biological processes interact at hourly and weekly time scales. The processes controlling the formation and dissipation of phytoplankton patches, are closely related in the coastal marine environment, therefore it is hard to separate and quantify the contributions related to each aggregation process (Dustan \& Pinckney 1989, Weiss et al. 1997).

Concerning heterogeneity over space, these results show an inverse relationship, when heterogeneity is low, the geographical distribution is larger, while when heterogeneity increases, it becomes more local and dissarrange; this has also been observed sequentially in terrestrial ecosystems (Gerstmann et al. 2010). The presence of spatial structures of phytoplankton assemblages has been reported in other systems and at different observation scales. Gosselin et al. (1986) showed that the spatial phytoplankton heterogeneity in aquatic systems can result from a balance between physical processes (e.g., upwelling, circulation, mixing by winds or tides), which tend to homogenize the environment and the algae growth processes and at a lower scale, promote heterogeneity in phytoplankton biomass. Doney (2002) reported results from meso-scale variability by making approximations of semi-variograms showing a number of geographical patterns and coherence in a large range of physical and biological environments. This study also concludes that the range shows approximate values of 200-350 km near the Equator, and values $<50 \mathrm{~km}$, near the poles. The average size of the patches in the Inner Sea of Chiloé was $50 \mathrm{~km}$ for autumn and winter and $30 \mathrm{~km}$ for spring and summer.

At a mesoscale $(1-300 \mathrm{~km})$, the phytoplankton spatial structures are associated to physical features such as fronts and eddies (Strass 1992, Martin \& Srokosz 2002, Tzella \& Haynes 2007), being larger in places where the hydrographic conditions are favorable for the occurrence of upwelling/advection of deep waters (Strass 1992). Then, the directions of lower spatial variability (anisotropy) of the phytoplankton biomass in the study area could be related to parameters associated to the geography of the micro-basin, area encompassing the zone, river discharge, wind direction and intensity. 
A

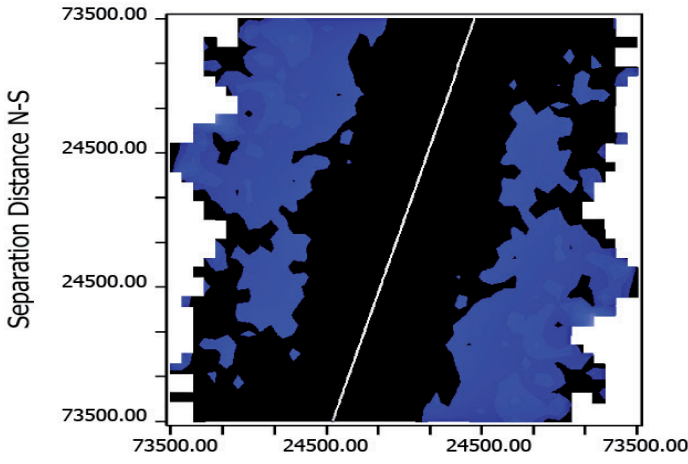

B

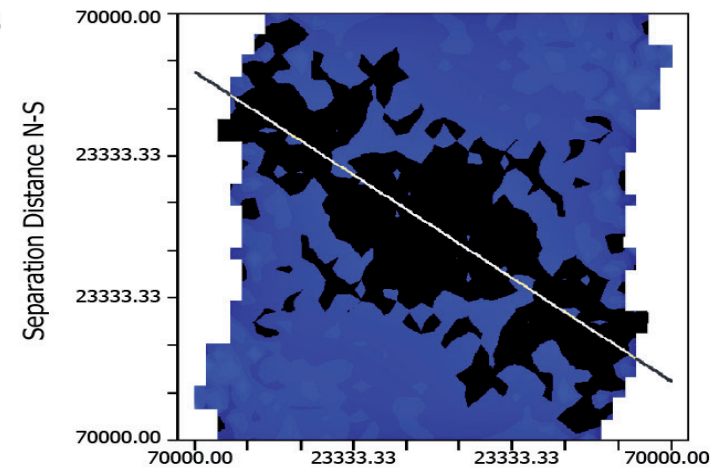

C
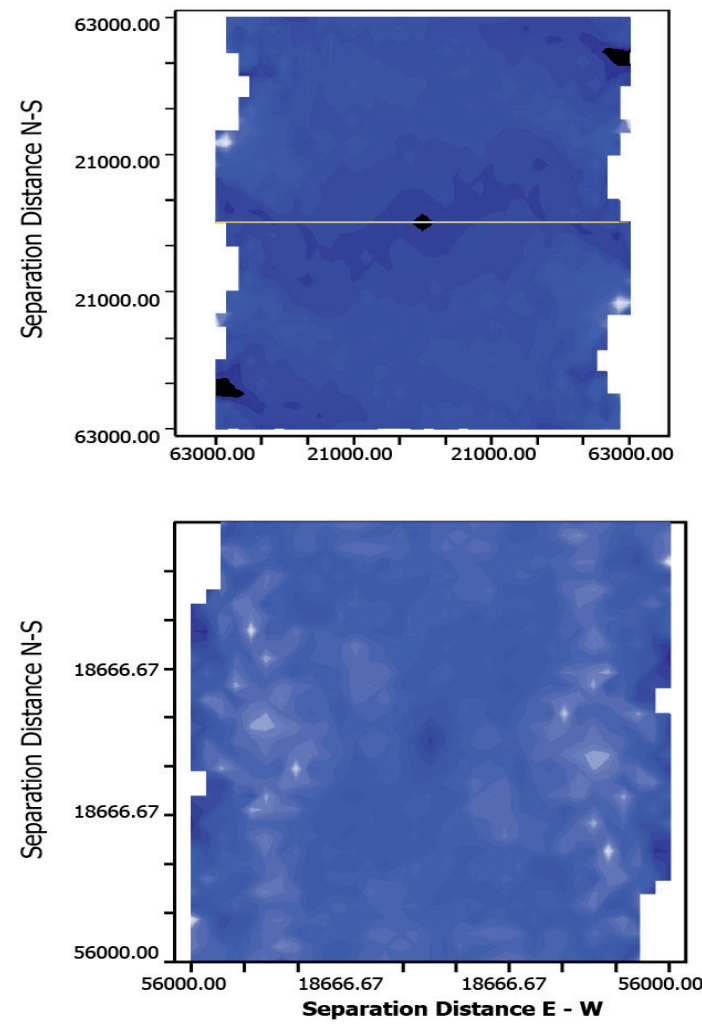

Figure 4. Variogram maps of the Inner Sea of Chiloé for A) summer, B) fall, C) winter and D) spring. White line indicate axe of anisotropy / Variogramas del Mar Interior de Chiloé para A) verano, B) otoño, C) invierno y D) primavera. Línea blanca indica eje de anisotropía
Nevertheless a spatial self-organization effect is expected in phytoplankton communities with mesoscale expression and physiographic (topography) and climate variables (precipitation, radiation and temperature), at regionalglobal scales (El Niño, Global Change).

The analysis of satellite images MODIS-AQUA performed in this study, validated seasonal pattern of $\mathrm{Chl}-a$, typical of temperate coastal environments from the southern-austral region of Chile. Chl- $a$ pattern showed a clear spatial variability, which showed patch structures in the Inner Sea of Chiloé at the scale employed $(150 \times 50 \mathrm{~km})$ during spring and summer according to geostatistical analysis. The difference between the three distinctive zones (Ancud Gulf, Islands Zone, Oceanic Zone-Guafo Mouth) in terms of Chl- $a$, can be explained mainly by climatological processes (wind, radiation), freshwater flows and oceanographic physical/chemical processes such as stratification / mixing, and nutrients. Finally, geostatistics approach could be used as a tool for identifying meso-scale spatial features of biological parameters such as phytoplankton biomass from aquatic systems.

\section{ACKnowledgments}

The authors thank the National Aeronautics and Space Administration (NASA) for making the MODIS images available; without them, this study would not have been possible. They also thank the valuable comments provided by the reviewers of this manuscript.

\section{LITERATURE CITED}

Acha E, H Mianzan \& R Guerrero. 2004. Marine fronts at the continental shelves of austral South America, physical and ecological processes. Journal of Marine Systems 44: 83-105.

Ahumada R, P Matrai \& N Silva. 1991. Phytoplankton biomass distribution and relationship to nutrient enrichment during an upwelling event off Concepción Bay, Chile. Boletín de la Sociedad de Biología de Concepción 62: 7-19.

Austerlitz F, C Dutech, P Smouse, F Davis \& V Sork. 2007. Estimating anisotropic pollen dispersal: a case study in Quercus lobata. Heredity 99: 193-204.

Avaria S. 1975. Estudios de ecología fitoplantónica en la bahía de Valparaíso II. Fitoplancton 1970-1971. Revista de Biología Marina 15(2): 131-148.

Avaria S \& E Orellana. 1975. Estudios de ecología fitoplantónica en la bahía de Valparaíso. III. Fitoplancton 1972-1973. Revista de Biología Marina 15(3): 207-226. 
Burrough PA. 1996. Principles of geographical information system for land resources assessment, $193 \mathrm{pp}$. Clarendon Press, Oxford.

Cáceres M, V Valle-Levinson, HH Sepulveda \& K Holderied. 2002. Transverse variability of flow and density in Chilean Fjords. Continental Shelf Research 22: 1683-1698.

Chernick M. 1999. Bootstrap methods: a practitioner's guide, 264 pp. Wiley, New York.

Doney S. 2002. Mesoscale variability of SeaWiFS satellite ocean color: Global patterns and spatial scales. Journal of Geophysical Research 108(C2), 3024 $<$ doi:10.1029/2001JC000843>

Dustan P \& J Pinckney. 1989. Tidally induced estuarine phytoplankton patchiness. Limnology and Oceanography 34(2): 410-419.

Fortin M. 1999. Spatial statistics in landscape ecology. In: Klopatek JM \& RH Gardner (eds). Landscape ecological analysis. Issues and applications, pp. 253-279. Springer \& Verlag, New York.

Fortin M \& M Dale. 2005. Spatial analysis, 365 pp. Cambridge University Press, Cambridge.

Fortin M-J, MRT Dale \& J ver Hoef. 2002. Spatial analysis in ecology. In: El-Shaarawi A \& W Piegorsch (eds). Encyclopedia of environmetrics 4: 2051-2058. John Wiley, Chichester.

Garrigues S, D Allard, F Baret \& M Weiss. 2006. Quantifying spatial heterogeneity at the landscape scale using variogram models. Remote Sensing of Environment 103: 81-96.

Geider R, H Maclntyre \& TM Kana. 1998. A dynamic regulatory model of phytoplanktonic acclimation to light, nutrients, and temperature. Limnology and Oceanography 43(4): 679-694.

Gerstmann C, M Miranda \& A Condal. 2010. Description of space-time variability of the potential productivity of Acacia caven espinales based on MODIS images and the Enhanced Vegetation Index (EVI). Ciencia e Investigación Agraria 37(1): 63-73.

González HE, S Pantoja, JL Iriarte \& P Bernal. 1989. Winter-spring variability of size fractionated autotrophic biomass in Concepcion Bay, Chile. Journal of Plankton Research 11: 1157-1167.

González HE, MJ Calderón, L Castro, L Clement, LA Cuevas, D Daneri, JL Iriarte, L Lizárraga, M Martínez, E Menschel, N Silva, C Carrasco, C Valenzuela, CA Vargas \& C Molinet. 2010. Primary production and plankton dynamics in the Reloncaví Fjord and the Interior Sea of Chiloé, Northern Patagonia, Chile. Marine Ecology Progress Series 402: 13-30.

Gosselin M, L Legendre, JC Therriault, S Demers \& M Rochet. 1986. Physical control of the horizontal patchiness of sea-ice microalgae. Marine Ecology Progress Series 29: 289-298.

Gregg WW \& ME Conkright. 2002. Decadal changes in the global ocean chlorophyll. Geophysical Research Letters 29 $<10.1029 / 2002$ GL014689>

Iriarte JL \& HE González. 2004. Phytoplankton size structure during and after the 1997/98 El Niño in a coastal upwelling area of the northern Humboldt Current System. Marine Ecology Progress Series 269: 83-90.

Iriarte JL, HE González, KK Liu, C Rivas \& C Valenzuela. 2007. Spatial and temporal variability of chlorophyll and primary productivity in surface waters of southern Chile (41.5-43 ${ }^{\circ}$ S). Estuarine, Coastal and Shelf Science 74: 471480.

Isaaks EH \& RM Srivastava. 1989. An introduction to applied geostatistics, 592 pp. Oxford University Press, New York.

Legendre P \& MJ Fortin. 1989. Spatial pattern and ecological analysis. Plant Ecology 80(2): 107-138.

Legendre P \& P Legendre. 2003. Numeral ecology, 853 pp. Elsevier Science, Amsterdam.

Marín V, L Delgado \& G Luna-Jorquera. 2003. S-chlorophyll squirts at $30^{\circ} \mathrm{S}$ off the Chilean Coast (Eastern South Pacific): feature-tracking analysis. Journal of Geophysical Research 108(C12), 3378 <doi:10.1029/2003JC001935>

Martin AP \& MA Srokosz. 2002. Plankton distribution spectra: inter-size class variability and the relative slopes for phytoplankton and zooplankton. Geophysical Research Letters 29(24), $2213<10.1029 / 2002$ GL015117>

Michelakaki M \& D Kitsiou. 2005. Estimation of anisotropies in Chlorophyll spatial distributions based on satellite data and variography. Global NEST Journal 7(2): 204-211.

Miranda M. 2007. Modélisation de la productivité forestière de Pinus radiata $\mathrm{D}$. Don à partir de patrons de variabilité spatio-temporelle de l'espèce et de l'environnement. Thèse Doctorale, Faculté de Foresterie et de Géomatique, Université Laval, Québec, 134 pp.

Miranda-Salas M \& A Condal. 2003. Importancia del análisis estadístico exploratorio en el proceso de interpolación espacial: caso de estudio Reserva Forestal Valdivia. Revista Bosque 24(2): 29-42.

Montecino V, T Strub, F Chavez, A Thomas, J Tarazona \& $\mathbf{T}$ Baumgartner. 2006. Bio-physical interactions off Western South-America. In: Robinson AR \& KH Brink. The global coastal ocean: interdisciplinary regional studies and syntheses (eds.). The Sea 14A: 329-390. John Wiley, New York.

Montecino V, P Uribe, D Soto, H González, J Riveros, G Alarcón, S Giglio, V Martinez \& M Paredes. 2009. Bio-óptica y diversidad de tamaños del fitoplancton en el Mar Interior de Chiloé: Variabilidad espacial en invierno- 
primavera 2004-2005. Ciencia y Tecnologia del Mar 32(2): 79-100

Morales C, JL Blanco, M Braun, H Reyes \& N Silva. 1996. Chlorophyll- $a$ distribution and associated oceanographic conditions in the upwelling region off northern Chile during the winter and spring 1993. Deep-Sea Research I 43(3): 267-289.

Palma S \& N Silva. 2004. Distribution of siphonophores, chaetognaths, euphausiids and oceanographic conditions in the fjords and channels of southern Chile. Deep-Sea Research II 51: 513-535.

Ramírez B \& G Pizarro. 2005. Distribución de la clorofila y feopigmentos en los canales australes chilenos comprendidos entre Puerto Montt y la laguna San Rafael, Chile. Ciencia y Tecnología del Mar 28(1): 45-62.

Rodríguez L, O Zárate \& E Oyarce. 1986. Productividad primaria del fitoplancton y su relación con la temperatura, oxígeno, nutrientes y salinidad en la bahía de Mejillones sur. Revista de Biología Marina 22(1): 75-96.

Rosenberg M. 2004. Wavelet analysis for detecting anisotropy in point patterns. Journal of Vegetation Science 15: 277284.

Strass VH. 1992. Chlorophyll patchiness caused by mesoscale upwelling at fronts. Deep-Sea Research I 39: 75-96.

Strub PT, J Mesías, V Montecino, J Rutllant \& S Salinas. 1998. Coastal ocean circulation off Western South America. In: Robinson AR \& KH Brink (eds). The global coastal ocean: Regional studies and syntheses. The Sea 11: 273-314. John Wiley, New York.

Tello A \& C Rodríguez-Benito. 2009. Characterization of mesoscale spatio-temporal patterns and variability of remotely sensed Chl $a$ and SST in the Interior Sea of Chiloe (41.4-43.5 ${ }^{\circ}$ S). International Journal of Remote Sensing 30: 1521-1536.

Therriault JC \& T Platt. 1978. Spatial heterogeneity of phytoplankton biomass and related factors in the nearsurface waters of an exposed coastal embayment. Limnology and Oceanography 23(5): 888-899.

Turner M, RH Gardner \& RV O'Neill. 2001. Landscape ecology in theory and practice: pattern and process, 404 pp. Springer- Verlag, New York.

Tzella A \& PH Haynes. 2007. Small-scale spatial structure in plankton distributions. Biogeosciences 4: 1791-1808.

Wang B \& S Yu. 2005. Multi-scale analyses of population distribution patterns. Acta Phytoecologica Sinica 29(2): 235-241.

Wang B, S Yu \& Y Wang. 2007. Anisotropy analysis of population distribution patterns. Frontiers of Biology in China 2(3): 356-361.

Waters R, J Mitchell \& J Seymour. 2003. Geostatistical characterisation of centimetre-scale spatial structure of in vivo fluorescence. Marine Ecology Progress Series 251: 49-58.

Weiss M, L Harding, E Itsweire \& J Campbell. 1997. Characterizing lateral variability of phytoplankton chlorophyll in Chesapeake Bay with aircraft ocean color data. Marine Ecology Progress Series 149: 183-199.

Yuras G, O Ulloa \& S Hormazábal. 2005. On the annual cycle of coastal and open ocean satellite chlorophyll off Chile $\left(18^{\circ}-40^{\circ} \mathrm{S}\right)$. Geophysical Research Letters 32, L23604 <doi:10.1029/2005GL023946>

Recibido el 05 de noviembre de 2009 y aceptado el 29 de marzo de 2010 